\title{
Adölesanların Madde Bağımlılığından Korunmaya iliş̧kin Öz Yeterlikleri ile Ebeveyn Bağlanma Düzeyleri Arasındaki İlişki
}

\section{Relationship Between Adolescents' Self-Efficacy for Protection from Substance Abuse and Parental Attachment Levels}

\author{
Fatma Ayhan 1(iD), Mehtap Genç ${ }^{2}$ (iD), Ayşe Sonay Türkmen 3 ${ }^{3}$ (D) \\ 1. Batman Üniversitesi Sağlık Yüksekokulu Hemşirelik Bölümü, Ruh Sağlığı ve Psikiyatri Hemşireliği Anabilim Dalı, Batman \\ 2. Karamanoğlu Mehmetbey Üniversitesi Sağık Bilimleri Fakültesi, Ruh Sağlığı ve Psikiyatri Hemşireliği Anabilim Dalı, Karaman \\ 3. Karamanoğlu Mehmetbey Üniversitesi Sağlık Bilimleri Fakültesi, Çocuk Sağlığı ve Hastalıkları Hemşireliği Anabilim Dalı, Karaman
}

\section{Abstract}

Objective: This study was conducted to determine the correlation between self-efficacy for substance addiction prevention and parental attachment levels of adolescents.

Method: A total of 120 adolescents participated in this study, which was conducted as a descriptive correlational study. The data collection tools include "Personal Information Form", "Self-Efficacy Scale for Protection from Substance Addiction (SESPSA)" and "Parental Bonding Instrument (PBI)" applied to the participants.

Results: Adolescents' average SESPSA total score is $76.47 \pm 28.31$. A significant correlation was found between the average total and subscale SESPSA scores and certain demographic characteristics of adolescents. It was revealed that the protection levels of female adolescents, whose mothers were secondary school graduates had higher protection from substance addiction. It was discovered that there was a significant difference between adolescents' substance using status and parental attachment rates.

Conclusion: Therefore, adolescents are at risk for substance abuse. Especially as the low maternal education level, male gender and negative parental attitudes increase this risk ratio for adolescents. It is recommended to plan protection, prevention and early diagnosis and for these groups, which are found to have a higher risk for substance addiction.

Keywords: Adolescent, substance abuse, self-efficacy, attachment

Öz

Amaç: Bu araştırma, adölesanların madde bağımlıı̆ından korunma öz yeterliklerinin ebeveyn bağlanma düzeyleri ile ilişkisini belirlemek amacı ile yapıımıştır.

Yöntem: Tanımlayıcı türde ilişki arayıcı olarak yapılan bu araştırmaya toplam 120 adölesan katıldı. Veri toplama aracı olarak; katılımcılara "Kişisel Bilgi Formu", "Madde Bağımlılığından Korunma Öz-Yeterlik Ölçeği (MBKÖÖ)" ve "Ana Babaya Bağlanma Ölçeği (ABBÖ-)" uygulandı.

Bulgular: Adölesanların MBKÖÖ toplam puan ortalamaları $76,47 \pm 28,31$ 'dir. MBKÖÖ toplam ve alt boyut puan ortalamaları ile adölesanların bazı demografik özellikleri arasında ilişki tespit edildi. Annesi ortaöğretim ve üzeri mezunu, kadın cinsiyetinde olan adölesanların madde bağımlıı̆ından korunma düzeylerinin daha iyi düzeyde olduğu saptandı. Adölesanların madde kullanım durumları ve anne babaya bağlanma düzeyleri arasında anlamlı farkllık olduğu görüldü.

Sonuç: Adölesanlar madde kullanımı açısından risk altındadır. Özellikle anne eğitim düzeyinin düşük olması, erkek cinsiyet ve olumsuz ebeveyn tutumları adölesanların risk oranını artırmaktadır. Madde bağımlıı̆̆ riskinin yüksek olduğu tespit edilen bu gruplarda koruma, önleme ve erken teşhis hizmetlerinin planlanması önerilmektedir.

Anahtar kelimeler: Adölesan, madde bağımlılığı, öz yeterlilik, bağlanma 


\section{Giriş}

Madde bağımlıı̆ı, alkol ve yasadışı uyuşturucular da dâhil olmak üzere psikoaktif maddelerin zararlı veya tehlikeli kullanımını ifade eder. Madde kullanımı; ailelerin ve toplumların sağlık, sosyal ve ekonomik düzeyleri için tehdit oluşturan karmaşık ve çok boyutlu bir sorundur (1).

Adölesan dönem; bireylerin bilişsel yönetim becerilerinin yeterli düzeyde gelişmemiş olması nedeniyle; madde kullanımı, şiddet, zorbalık ve güvensiz cinsel ilişki gibi dürtüsel eylem risklerinin oldukça fazla olduğu bir gelişim sürecidir (2). Son yıllarda adölesanlar arasındaki alkol tüketimi çok erken yaşlara kadar inmiş ve toplum için ciddi bir sorun haline gelmiştir (3). Madde kullanımı ve alkolün zararlı kullanımı; yaralanmalar, kazalar (4), kendine zarar verme gibi diğer riskleri de tetikleyerek adölesanları birçok olumsuz durumla karşı karşıya getirmektedir (5). Dünya Sağlık Örgütü'ne (2017) göre, adölesanlarda alkol ve yasadışı uyuşturucu kötüye kullanımı birçok ülkede büyük bir endişe kaynağıdır (1).

Bireyi bağımlıık riskinden koruyan faktörler arasında; bireyin aile çevresi ve akranlarılla ilişkisi ön plana çıkmaktadır (6). Adölesan dönem boyunca birey özerklik kazandıkça, akran grubunun etkisi artmakta, ebeveynlerin etkisi ise azalmaktadır (7). Ancak, bireylerin aile çevresinde etkili bir ilişkinin varlığı, bireyleri adölesan dönemde de ebeveynlerini temel referans noktası olarak görmeye devam etmeleri konusunda destekler (2). Akran grubunda çok sayıda psikoaktif madde kullanılmasına rağmen adölesanın madde kullanan grubu tercih edip etmemesi yine aile ilişkilerinin kalitesine bağlıdır $(8,9)$. Adölesan dönemde aile ve akranlarla olan bu ilişkiler, bireyin duygusal dengesini etkilemekte, duygusal dengeyi düzenlenme becerisinin düşük olması da alkol ve diğer maddelerin kötüye kullanım riskini artırmaktadır $(10,11)$.

Bowlby'ye göre ebeveynlerle kurulan bağ, çoğu birey için yetişkin yaşamında da devam eder ve bireyin davranışlarını birçok şekilde etkiler. Bağlanma teorisi, ebeveynlerle kurulan bağların gelecekteki ilişkiler üzerinde önemli bir etkiye sahip olduğunu varsayar. Bağlanma modeline göre; ebeveyn desteği adölesanın ilişkiler hakkında geliştirdiği şemaya katkıda bulunur ve bu şema, akranlarla ilişkileri yorumlama ve eylemde bulunma için bir temel oluşturur. Şema, bireye çevrenin akla uygun bir şekilde değerlendirilmesini ve problemli veya tehlikeli yönlerinden uzak durmayı sağlayan bir harita sağlar. Destekleyici şekildeki bağlanma, bireyi başarılı çevresel deneyimlere teşvik eder ve bu başarılar bireyin olumlu bir benlik saygısı kazanmasını sağlar (12). Ebeveyn desteği ve ebeveyn takibinin marijuana, alkol ve kokain bağımlı̆̆ğ, okul suistimali, suç davranışlarının ve uygunsuz davranışların sıklığını (13) ve madde bağımlığını azaltması (14,15), güvenli bağlanmanın bireyi madde bağımıı̆ığından koruduğu yönündeki görüşleri destekler. Bununla birlikte, güvensiz bağlanma türünün bireylerde zaman zaman madde tüketiminin düzenli ve kalıcı bir hale gelmesine neden olması (16) güvensiz bağlanmanın bağımlılık üzerindeki önemini ortaya koyar.

Bağımlıı̆ın gelişimi sosyal öğrenme modeline göre ele alındığında yine ailenin önemli bir etken olduğu görülmektedir. Erken çocukluktan itibaren, model alma, taklit etme ve özdeşim kurmanın davranışlar üzerindeki etkisi açıktır (17). Bu bağlamda madde kullanımı için bir model oluşturan ebeveynlere sahip adölesanlar, madde kullanımına daha yatkındır.

Yukarıdaki bilgiler ışığında adölesanlarda madde bağımlıı̆ı ile ebeveyn bağlanma düzeyleri arasında bir ilişki olduğunu söylemek mümkündür. Adölesanlarda madde bağımlıı̆̆ının önlenmesi ve erken müdahale stratejilerinin geliştirilebilmesi için ise adölesanların madde bağımlılı̆ından korunma öz yeterliklerinin hangi faktörlerden etkilendiğinin belirlenmesi gereklidir. Literatürde adölesanların madde bağımlıı̆ından korunma öz yeterlikleri ile ebeveynlerine bağlanma düzeyleri arasındaki ilişkiyi değerlendiren bir araştırmaya rastlanmamıştır. Bu nedenle bu çalışmada, adölesanların ebeveynlerine bağlanma düzeyleri ile madde bağımlılığından korunma öz yeterlikleri arasındaki ilişkinin belirlenmesi amaçlanmıştır. Son yıllarda yapılan çalışmalar; Türkiye'de mesleki eğitim merkezine devam eden adölesanlarda sigara kullanımının $\% 41,9$, alkol kullanımının \%39,8 (18), yasadışı madde kullanımının ise \%9,8 gibi ciddi oranlara ulaştığını ortaya koymaktadır (19). Bu nedenle, çalışmanın bir mesleki eğitim merkezine devam eden adölesanlarla yapılmasının çalışmanın amacına uygun olacağı düşünülmüştür. 


\section{Yöntem}

\section{Örneklem}

Araştırma tanımlayıcı ve ilişki arayıcı türde araştırma tasarımında gerçekleştirildi. Araştırmanın evrenini İç Anadolu Bölgesi'ndeki bir il merkezinde yer alan bir mesleki eğitim merkezine 1-20 Haziran 2020 tarihleri arasında devam eden adölesanlar oluşturdu. Örneklem büyüklüğü, Dünya Sağlık Örgütü tarafından yayınlanan Sağlık Çalışmalarında Örneklem Hesaplaması Rehberi'ne göre; \%95 güven aralığında 0,04 hata payı ve \%95 güç ile 114 adölesan olarak belirlendi (20). Çalışmanın örneklemini araştırmaya katılmayı kabul eden ve veri toplama araçlarını eksiksiz dolduran toplam 120 adölesan oluşturdu.

\section{İşlem}

Çalışmanın yürütülebilmesi için Karamanoğlu Mehmetbey Üniversitesi Girişimsel Olmayan Klinik Araştırmalar Etik Kurulu'ndan yazılı onay (Tarih: 27.05.2020, Karar No: 31) ve araştırmanın yapıldığı kurumdan yazıı izin alınmışıı. Ayrıca, katıımcıların çevrimiçi form üzerinden onayları alınmış ve çalışmaya katılım gönüllülük esasına dayanmıştır. Araştırmanın her aşamasında araştırma ve yayın etiğine uyulmuştur.

Çalışmanın verilerinin yüz yüze ve sınıf ortamında toplanması planlanmış olup, Covid-19 pandemisi nedeniyle veriler çevrimiçi olarak toplanmıştır. 'Google Forms' uygulaması üzerinden hazırlanan veri toplama aracının bağlantı linki, merkezin rehberlik öğretmeni aracılığılyla öğrencilere ulaştırımıştır. Katılımcılara iletilen formun illk bölümünde çalışmanın amacı hakkında bilgi verilmiş ve katılımcıların çalışmaya gönüllü olarak katılmayı kabul etmeleri durumunda form üzerinde "Çalışmaya katılmayı gönüllü olarak kabul ediyorum" şeklinde beyanlarını işaretleyecekleri bir onay kutusuna yer verilmiştir. Çalışmaya katılmaya gönüllü olan katılımcılar anket sorularını yanıtlamışlardır.

\section{Veri Toplama Araçları}

Veriler, "Kişisel Bilgi Formu", "Madde Bağımlılığından Korunma Öz-Yeterlik Ölçeği (MBKÖÖ)" ve "Ana Babaya Bağlanma Ölçeği (ABBÖ- The Parental Bonding Instrument; PBI)" kullanılarak toplandı.

\section{Kişisel Bilgi Formu}

Form, araştırmacılar tarafından literatüre dayalı olarak hazırlanmıştır $(18,19)$. Toplam 15 sorudan oluşan form içerisinde ailenin ve adölesanın demografik özellikleri ile madde kullanımına ilişkin sorular yer almaktadır.

\section{Madde Bağımllığından Korunma Öz-Yeterlik Ölçeği (MBKÖÖ)}

Ölçek, Eker ve arkadaşları (2013) tarafından lise öğrencilerinin madde bağımılı̆̆ından korunmaya ilişkin öz-yeterlik algılarını ölçmek amacıyla geliştirilmiştir. Beşli likert tipinde (1: hiç emin değilim; 5: son derece eminim) geliştirilen bu ölçek toplam 24 madde ve dört alt boyuttan oluşmaktadır. Bu alt boyutlar; uyuşturucu/uyarıcı maddelerden uzak durma $(3,5,6,7,8,10,11,16,17,19,20$ ve 23), baskı altındayken uyuşturucu/uyarıcı maddelerden uzak durma (18, 21, 22 ve 24), uyuşturucu/uyarıcı maddeler konusunda yardım arama (12, 13, 14 ve 15) ve uyuşturucu/uyarıc maddeler konusunda arkadaşına destek olma (1, 2 ve 9)'dır. Ölçekte yer alan 2. soru kontrol sorusu olup ölçek toplam puanlamasında değerlendirme kapsamı dışında bırakılmaktadır. Ölçekten alınabilecek en düşük puan 23, en yüksek puan ise 115 'tir. Ölçek toplam puanının yüksekliği, madde bağımlıı̆ından korunmada öz-yeterliğin yüksekliğine işaret edeceği şeklinde yorumlanabilir. Ölçeğin Cronbach Alfa katsayısı 0,81 olarak belirlenmiştir (21).

\section{Ana Babaya Bağlanma Ölçeği (ABBÖ- The Parental Bonding Instrument; PBI)}

Parker ve arkadaşlarının (1979) geliştirmiş olduğu ABBÖ, kişinin yaşamının ilk 16 ylında ebeveynlerinden algıladığı tutum ve davranışları retrospektif bir biçimde değerlendirir. Ölçeğin Türkçe geçerlik ve güvenilirliği 2006 yılında Kapçı ve Küçüker tarafından yapılmıştır. Ölçek, anne ve baba formu olarak iki şekilde hazırlanmıştır. Anne ve baba formunda yer alan sorular aynı olup, ilgi-kontrol ve aşırı koruma olarak 
adlandırılan iki alt boyuttan ve 25'er maddeden oluşmaktadır. Iligi-kontrol alt boyutu; 1, 2, 3, 4, 5, 6, 7, 11 , $12,14,15,16,17,18,21,22,24$ ve 25. maddeler olmak üzere toplam 18 maddeden; așırı koruma alt boyutu; 8, 9, 10, 13, 19, 20 ve 23 maddeler olmak üzere toplam 7 maddeden oluşmaktadır. Ölçekte yer alan $2,4,8,9,10,13,14,16,18,19,20,23$ ve 24. maddeler ters kodlanmaktadır. Ölçek tamamen böyleydi $=3$; hiç böyle değildi $=0$ şeklinde puanlanmaktadır. Ölçeğin aşırı koruma alt boyutundan alınabilecek puan 0-21 arasında, ilgi-kontrol alt boyutundan alınabilecek puan 0-54 arasında değişmektedir. Ölçeğin test-tekrar test güvenirliği ilgi boyutu için 0,76 , aşırı koruma/kontrol boyutu için 0,63 , yarıya bölme güvenirliği sırası ile 0.88 ve 0.74 olarak, gözlemciler arası güvenirlik katsayısı ise 0,85 ve 0,69 olarak bulunmuştur. Hem toplam ölçekte, hem de iki alt ölçekte puan artışı olumlu bağlanmayı ifade etmektedir. Ölçek ve alt boyutlarının kesme noktası bulunmamaktadır (22).

\section{Veri Analizi}

Veriler, Statistical Package for the Social Sciences (SPSS)-21.00 paket programı kullanılarak değerlendirilmiştir. Katılımcıların tanııı özelliklerinin değerlendirmesinde; tanımlayıcı istatistiksel yöntemlerden frekans, yüzde, aritmetik ortalama ve standart sapma kullanılmıştır. MBKÖÖ ile ABBÖ ölçekleri ve kullanılan madde türleri arasındaki ilişkilerin belirlenmesi için Korelasyon analizi yapılmıştır. Adölesanların bazı tanıtıcı özellikleri ile MBKÖ ölçek puan ortalamalarının karşılaştırıması, ABBÖ ve alt boyutlarından aldıkları puan ortalamalarının madde kullanım durumlarıyla karşılaştırmasında; iki değişkenli gruplar için Ki-kare Testi, üç ve daha fazla değişkenli gruplar için grupların Kruskall Wallis Varyans analizi ve farkın hangi gruptan kaynaklandığının tespit edilmesi için One Way Anowa testinin varyansların eşit olmadığı durumlarda kullanılan Tamhane's T2 post hoc karşılaştırması kullanıımışıı.

\section{Bulgular}

Çalışmaya dahil edilen adölesanların yaş gruplarına göre dağılımları benzer olup, çoğunluğu erkek $(\% 72,5)$ ve ailesi ile birlikte yaşamaktadır (\%92,5). Adölesanların \%40,8'i sigara, 20,8'i alkol, \%7,5'i diğer maddeleri kullandığını bildirmiştir (Tablo 1).

Adölesanların sigara, alkol ya da diğer maddeleri kullanma durumlarının birbiri ile ilişkisi incelendiğinde sigara kullanma durumu ile alkol ve diğer madde kullanımı arasında pozitif yönde, orta düzeyde anlamlı ilişki olduğu belirlendi. Ayrıca ailede alkol tüketen birinin varlığı ile adölesanın sigara, alkol ya da diğer maddeleri kullanma durumu arasında negatif yönde, zayıf ilişki olduğu görüldü (Tablo 2). Buna göre; adölesanın sigara içmesi alkol ya da diğer maddeleri kullanmasını artıırken, ailede alkol tüketiminin olması adölesanın tüm maddeleri tüketme durumunu azaltmaktadır.

Adölesanların uyuşturucu/uyarıcı maddelerden uzak durma alt boyut puan ortalaması 40,51 $\pm 15,55$, baskı altındayken uyuşturucu/uyarıcı maddelerden uzak durma alt boyut puan ortalaması $13,44 \pm 5,71$, uyuşturucu/uyarıcı maddeler konusunda yardım arama alt boyut puan ortalaması $12,88 \pm 5,19$, uyuşturucu/uyarıcı maddeler konusunda arkadaşına destek olma alt boyut puan ortalaması 9,64 $\pm 3,8$, toplam puan ortalaması ise $76,47 \pm 28,31$ 'dir.

Tablo 1. Adölesanların demografik özelliklerine göre dağılımları $(n=120)$

\begin{tabular}{|c|c|c|}
\hline Demografik Özellikler & Sayı & Yüzde \\
\hline \multicolumn{3}{|l|}{ Yas } \\
\hline $15 \mathrm{yll}$ & 30 & 25,0 \\
\hline $16 \mathrm{yll}$ & 28 & 23,3 \\
\hline $17 \mathrm{yll}$ & 36 & 30,0 \\
\hline $18 \mathrm{yll}$ & 26 & 21,7 \\
\hline \multicolumn{3}{|l|}{ Cinsiyet } \\
\hline Kadın & 33 & 27,5 \\
\hline Erkek & 87 & 72,5 \\
\hline \multicolumn{3}{|l|}{ Yaşadığı kişiler } \\
\hline Aile & 111 & 92,5 \\
\hline
\end{tabular}




\begin{tabular}{|c|c|c|}
\hline Arkadaş/arkadaşlar & 3 & 2,5 \\
\hline Yalnız & 6 & 5,0 \\
\hline \multicolumn{3}{|c|}{ Annenin eğitim durumu } \\
\hline İlköğretim & 99 & 82,5 \\
\hline Lise ve üstü & 21 & 17,5 \\
\hline \multicolumn{3}{|l|}{ Annenin mesleği } \\
\hline Çalışıyor & 34 & 28,3 \\
\hline Ev hanımı & 86 & 71,7 \\
\hline \multicolumn{3}{|c|}{ Babanın eğitim durumu } \\
\hline İlköğretim & 90 & 75,0 \\
\hline Lise ve üstü & 30 & 25,0 \\
\hline \multicolumn{3}{|l|}{ Babanın mesleği } \\
\hline İşçi & 61 & 50,8 \\
\hline Kamu çalışanı & 10 & 8,3 \\
\hline Serbest meslek & 37 & 30,8 \\
\hline Çalışmıyor & 12 & 10,1 \\
\hline \multicolumn{3}{|l|}{ Kardeş sayısı } \\
\hline 1 & 17 & 14,2 \\
\hline 2 & 28 & 23,3 \\
\hline 3 & 48 & 40,0 \\
\hline 4 ve daha fazla & 27 & 22,5 \\
\hline \multicolumn{3}{|l|}{ Ailenin gelir durumu } \\
\hline Gelir giderden az & 20 & 16,7 \\
\hline Gelir gidere eșit & 69 & 57,5 \\
\hline Gelir giderden fazla & 31 & 25,8 \\
\hline \multicolumn{3}{|c|}{ Herhangi bir işte çalışma durumu } \\
\hline Çalışıyor & 98 & 81,7 \\
\hline Calıșmıyor & 22 & 18,3 \\
\hline \multicolumn{3}{|c|}{ Sigara kullanma durumu } \\
\hline Kullanmıyor & 63 & 52.5 \\
\hline Kullanıyordu bıraktı & 8 & 6.7 \\
\hline Kullaniyor & 49 & 40.8 \\
\hline \multicolumn{3}{|c|}{ Alkol kullanma durumu } \\
\hline Kullanmıyor & 84 & 70.0 \\
\hline Kullanıyordu bıraktı & 11 & 9.2 \\
\hline Kullaniyor & 25 & 20.8 \\
\hline \multicolumn{3}{|c|}{ Diğer maddeleri kullanma durumu } \\
\hline Kullanmıyor & 107 & 89.2 \\
\hline Kullanıyordu bıraktı & 4 & 3.3 \\
\hline Kullaniyor & 9 & 7.5 \\
\hline \multicolumn{3}{|c|}{ Ailenin sigara kullanma durumu } \\
\hline Kullanilıyor & 61 & 50.8 \\
\hline Kullanılmıyor & 59 & 49.2 \\
\hline \multicolumn{3}{|c|}{ Ailenin alkol kullanma durumu } \\
\hline Kullanilıyor & 6 & 5.0 \\
\hline Kullanılmıyor & 114 & 95.0 \\
\hline \multicolumn{3}{|c|}{ Ailenin diğer maddeleri kullanma durumu } \\
\hline Kullanilıyor & 3 & 2.5 \\
\hline Kullanılmıyor & 117 & 97.5 \\
\hline
\end{tabular}

Adölesanların MBKÖÖ puan ortalamasının adölesanın, cinsiyeti ve annesinin eğitim durumuna göre anlamlı farkllık gösterdiği belirlendi. Cinsiyetlere göre MBKÖÖ toplam ve alt boyut puan ortalamaları incelendiğinde kadınların MBKÖÖ toplam ve alt boyut puan ortalamalarının daha yüksek olduğu bulundu. Annelerin eğitim 
durumu arasında karşılaştırma yapıldığında ise; lise ve üzerinde eğitim almış anneye sahip olan adölesanların baskı altında hayır diyebilme oranlarının daha yüksek olduğu belirlendi (Tablo 3).

Tablo 2. Adölesanların madde kullanma durumları arasındaki ilişki* $(n=120)$

\begin{tabular}{|c|c|c|c|}
\hline & $\begin{array}{l}\text { Adölesanın sigara } \\
\text { kullanma durumu }\end{array}$ & $\begin{array}{c}\text { Adölesanın diğer } \\
\text { maddeleri kullanma } \\
\text { durumu }\end{array}$ & $\begin{array}{c}\text { Adölesanın alkol } \\
\text { kullanma durumu (\%) }\end{array}$ \\
\hline Ailede alkol & $r=-, 108 \quad p=0,242$ & $r=-, 185, p=, 043$ & $r=-, 203, p=0,027$ \\
\hline $\begin{array}{l}\text { Adölesanın alkol } \\
\text { kullanma durumu }\end{array}$ & $r=, 533, p=0,000$ & $r=, 444, p=, 000$ & 1 \\
\hline $\begin{array}{l}\text { Adölesanın diğer } \\
\text { maddeleri kullanma } \\
\text { durumu }\end{array}$ & $r=, 184, p=0,045$ & 1 & $r=, 444, p=0,000$ \\
\hline
\end{tabular}

Tablo 3. Adölesanların yaş, cinsiyet ve annelerinin eğitim durumlarına göre MBKÖ ölçek puan ortalamalarının gruplar arası karşılaştırması $(n=120)$

\begin{tabular}{|c|c|c|c|c|c|}
\hline & $\begin{array}{l}\text { Uyuşturucu/uyar } \\
\text { ICI maddelerden } \\
\text { uzak durma }\end{array}$ & $\begin{array}{l}\text { Baskı } \\
\text { altındayken } \\
\text { uyuşturucu/ } \\
\text { uyarıcı } \\
\text { maddelerden } \\
\text { uzak durma }\end{array}$ & $\begin{array}{l}\text { Uyuşturucu/uyar } \\
\text { IcI maddeler } \\
\text { konusunda } \\
\text { yardım arama }\end{array}$ & $\begin{array}{l}\text { Uyuşturucu/uyar } \\
\text { IcI maddeler } \\
\text { konusunda } \\
\text { arkadaşına } \\
\text { destek olma }\end{array}$ & MBKÖÖ Toplam \\
\hline \multicolumn{6}{|l|}{$\begin{array}{l}\text { Adölesanın } \\
\text { yaşı }\end{array}$} \\
\hline $15 \mathrm{yll}$ & $42,63 \pm 18,19$ & $14,67 \pm 5,98$ & $13,93 \pm 5,72$ & $9,73 \pm 4,35$ & $80,97 \pm 33,12$ \\
\hline $16 \mathrm{yll}$ & $38,54 \pm 13,59$ & $12,86 \pm 4,96$ & $11,64 \pm 4,26$ & $9,46 \pm 3,63$ & $72,50 \pm 23,61$ \\
\hline $17 \mathrm{yll}$ & $37,44 \pm 15,95$ & $12,33 \pm 6,12$ & $11,75 \pm 5,27$ & $8,92 \pm 3,68$ & $70,44 \pm 29,47$ \\
\hline $18 \mathrm{yll}$ & $44,42 \pm 13,12$ & $14,19 \pm 5,45$ & $14,54 \pm 4,91$ & $10,73 \pm 3,55$ & $83,88 \pm 23,94$ \\
\hline $\mathrm{F}$ & 1.365 & 1,167 & 2,483 & 1.163 & 1,598 \\
\hline $\mathrm{p}$ & 0,257 & 0,326 & 0,064 & 0,327 & 0,194 \\
\hline \multicolumn{6}{|l|}{ Cinsiyet } \\
\hline Kadın & $48,24 \pm 14,32 \mathrm{a}$ & $16,55 \pm 4,65 a$ & $14,73 \pm 4,89 a$ & $11,55 \pm 3,46 \mathrm{a}$ & $91,06 \pm 25,47 a$ \\
\hline Erkek & $37,57 \pm 15,05 b$ & $12,26 \pm 5,64 b$ & $12,17 \pm 5,16 b$ & $8,92 \pm 3,73 b$ & $70,93 \pm 27,48 b$ \\
\hline$Z$ & $-3,607$ & $-3,841$ & $-2,449$ & $-3,686$ & $-3,686$ \\
\hline$p$ & 0,000 & $\begin{array}{l}0,000 \\
a>b\end{array}$ & 0,014 & 0,000 & $\begin{array}{c}0,000 \\
a>b\end{array}$ \\
\hline \multicolumn{6}{|l|}{$\begin{array}{l}\text { Annenin } \\
\text { Eğitim } \\
\text { Durumu }\end{array}$} \\
\hline İlköğretim & $39,77 \pm 15,80$ & $12,92 \pm 5,84 b$ & $12,60 \pm 5,25$ & $9,47 \pm 3,77$ & $74,76 \pm 28,78$ \\
\hline $\begin{array}{l}\text { Lise ve } \\
\text { üzeri }\end{array}$ & $44,00 \pm 14,16$ & $15,90 \pm 4,36 a$ & $14,19 \pm 4,83$ & $10,43 \pm 4,09$ & $84,52 \pm 25,06$ \\
\hline$Z$ & $-1,113$ & $-2,051$ & $-1,243$ & $-1,246$ & $-1,361$ \\
\hline$p$ & 0,266 & 0,040 & 0,214 & 0,213 & 0,173 \\
\hline
\end{tabular}

F: Kruskal wallis test değerini göstermektedir.; z: Mann-Whitney U test değerini göstermektedir.

ABBÖ puanları incelendiğinde anne ilgi kontrol alt boyut puan ortalaması 16,73 $\pm 9,08$ iken, baba ilgi kontrol puan ortalaması 19,80 $\pm 10,29$ idi. Anne aşırı koruma alt boyut puan ortalaması $13,33 \pm 3,97$ iken baba aşırı koruma alt boyut puan ortalaması 11,54 $\pm 4,68$ idi. ABBÖ alt boyut puan ortalamaları arasındaki ilişki değerlendirildiğinde, anne ilgi kontrol alt boyut puan ortalamasının, anne aşıı koruma puanı ile negatif yönde zayıf ( $r=-, 267 ; p=0,003)$, baba ilgi kontrol puanı ile pozitif yönde yüksek ( $r=, 622 ; p=0,000)$; baba aşırı koruma ile negatif yönde düşük düzeyde $(r=-, 240 ; p=0,009)$. ilişkili olduğu tespit edildi. Anne aşırı koruma puanının, baba ilgi kontrol puan ortalamaları ile negatif yönde zayıf ( $r=-, 168 ; p=0,067)$; baba aşırı koruma puanı ile pozitif yönde orta düzeyde $(r=0,470 ; p=0,000)$ ilişkili olduğu görüldü (Tablo 4). Baba ilgi 
kontrol puanının babanın aşııı koruma puanı ile negatif yönde orta düzeyde ( $r=-, 437 ; p=0,000)$ bir ilişki gösterdiği tespit edildi. Buna göre anne ilgili ise baba da ilgili yaklaşmaktadır. IIIgi puan ortalamaları ile aşırı koruma puan ortalamaları arasında ise negatif bir ilişki vardır.

\begin{tabular}{|c|c|c|c|c|}
\hline & Anne İlgi-Kontrol & Anne Așirı Koruma & Baba İlgi-Kontrol & Baba Așırı Koruma \\
\hline \multicolumn{5}{|l|}{ Sigara } \\
\hline Kullanmıyor & $14,85 \pm 7,19^{a}$ & $13,22 \pm 3.81$ & $17,35 \pm 9,75^{a}$ & $11,69 \pm 3,98$ \\
\hline Kullanıyordu bıraktı & $13,63 \pm 9,75^{a b}$ & $13,87 \pm 4,22$ & $19,87 \pm 13,35^{a b}$ & $12,25 \pm 6,98$ \\
\hline \multirow[t]{2}{*}{ Kullanıyor } & $19,71 \pm 10,45^{b}$ & $13,39 \pm 4,19$ & $22,93 \pm 9,79^{b}$ & $11,22 \pm 5,16$ \\
\hline & $a<b$ & & $a<b$ & \\
\hline $\begin{array}{l}F \\
p\end{array}$ & $\begin{array}{l}4,65 \\
0,011\end{array}$ & $\begin{array}{l}0,102 \\
0,903\end{array}$ & $\begin{array}{l}4,293 \\
0,016\end{array}$ & $\begin{array}{l}0,236 \\
0,790\end{array}$ \\
\hline \multicolumn{5}{|l|}{ Alkol } \\
\hline Kullanmıyor & $14,61 \pm 7,88^{a}$ & $13,79 \pm 3,71^{\mathrm{a}}$ & $17,05 \pm 9,92^{\mathrm{a}}$ & $12,18 \pm 4,25^{a}$ \\
\hline Kullanıyordu bıraktı & $18,63 \pm 10,11^{\text {ab }}$ & $14,64 \pm 3,35^{a}$ & $22,36 \pm 6,67^{b}$ & $13,09 \pm 2,98^{a}$ \\
\hline \multirow[t]{2}{*}{ Kullanıyor } & $22,92 \pm 9,69^{b}$ & $11,20 \pm 4,39^{b}$ & $27,92 \pm 8,79^{\text {bc }}$ & $8,72 \pm 5,65^{b}$ \\
\hline & $a<b$ & $b<a$ & $a<b$ & $b<a$ \\
\hline $\begin{array}{l}F \\
p\end{array}$ & $\begin{array}{l}9,49 \\
0,000\end{array}$ & $\begin{array}{l}5,11 \\
0,007\end{array}$ & $\begin{array}{l}13,46 \\
0,000\end{array}$ & $\begin{array}{l}6,45 \\
0,002\end{array}$ \\
\hline \multicolumn{5}{|l|}{ Diğer Maddeler } \\
\hline Kullanmıyor & $16,27 \pm 9,04$ & $13,75 \pm 3,85^{a}$ & $19,26 \pm 10,43$ & $11,66 \pm 4,41$ \\
\hline Kullanıyordu bıraktı & $23,50 \pm 3,69$ & $9,00 \pm 3,65^{a b}$ & $27,75 \pm 6,39$ & $5,25 \pm 5,56$ \\
\hline Kullanıyor & $19,11 \pm 10,36$ & $10,33 \pm 3,16^{b}$ & $22,66 \pm 8,50$ & $12,88 \pm 5,92$ \\
\hline$F$ & 1,56 & 6,01 & 1,71 & 4,23 \\
\hline \multirow[t]{2}{*}{$p$} & 0,213 & 0,003 & 0,185 & 0,17 \\
\hline & & $a>b$ & & \\
\hline
\end{tabular}

F: Kruskal wallis test değerini göstermektedir

MBKÖÖ puan ortalamaları ile ABBÖ puan ortalamaları arasındaki ilişki değerlendirildiğinde, ölçek puan ortalamaları arasında bir ilişki tespit edilmedi. Uyuşturucu/uyarıcı maddelerden uzak durma puanının, baskı altında iken uyuşturucu/uyarıcı maddelerden uzak durma puanı arasında pozitif yönde çok kuvvetli $(r=, 896$; $\mathrm{p}=0,000)$; uyuşturucu/uyarıcı maddeler konusunda yardım arama puanı ile pozitif yönde çok kuvvetli $(r=, 826 ; p=0,000)$; uyuşturucu/uyarıcı maddeler konusunda arkadaşına destek olma puanı ile pozitif yönde kuvvetli $(r=, 777 ; p=0,000)$ bir ilişki olduğu belirlendi. Baskı altında iken uyuşturucu/uyarıcı maddelerden uzak durma puanının, uyuşturucu/uyarıcı maddeler konusunda yardım arama puanı ile pozitif yönde kuvvetli $(r=, 758 ; p=0,000)$; uyuşturucu/uyarıcı maddeler konusunda arkadaşına destek olma puanı ile pozitif yönde kuvvetli $(r=710 ; p=0,000)$ şekilde ilişkili olduğu belirlendi. Uyuşturucu/uyarıcı maddeler konusunda yardım arama puanının, uyuşturucu/uyarıcı maddeler konusunda arkadaşına destek olma puanı ile pozitif yönde kuvvetli şekilde ilişkili olduğu saptandı $(r=, 622 ; p=0,000)$.

Adölesanların kullandıkları madde türüne göre anne babaya bağlanma düzeyleri arasında anlamlı farkılık olduğu görüldü. Sigara kullanan adölesanların anne ve baba ilgi-kontrol alt boyutlarından daha yüksek; alkol tüketen adölesanların anne ve baba ilgi-kontrol alt boyutlarından daha yüksek, anne ve baba aşırı koruma alt boyutlarından daha düşük; diğer madde kullanan adölesanların anne aşıı koruma puan ortalamalarının daha düşük ve farkın anlamlı olduğu belirlendi. Diğer maddeleri kullanmayan adölesanların kullanıp bırakanlara göre anne aşıı koruma puan ortalamasının daha yüksek olduğu saptandı (Tablo 4).

\section{Tartışma}

Pek çok kültürde, çocuklar özellikle akranları tarafından tanımlanan sosyal normlardan kolaylıkla etkilenir ve bu normlara uyma konusunda son derece heveslidir. Bu nedenle, madde kötüye kullanımı gibi deneyimlere 
karşı hassastırlar ve farkında olmadan maddelere bağımlı hale gelebilirler (23). Ebeveyn bağlanma örüntüleri ise adölesanlarda madde kullanım davranışlarının önemli yordayıcılarından biridir (24).

Adölesanların madde bağımlılığından korunma öz yeterliklerinin ebeveyn bağlanma düzeyleri ile ilişkisini belirlemek amacı ile yapılan bu çalışmada; adölesanların \%40,8'inin sigara, \%20,8'inin alkol, \%7,5'inin ise diğer maddeleri kullandığı belirlenmiştir. Literatürde adölesanlar arasında madde kullanım yaygınlığını analiz eden çalışmaların bulguları farkılık göstermektedir. İspanya'da 13 ve 19 yaşları arasındaki 668 adölesan üzerinde yürütülen bir çalışmanın sonuçları adölesan dönemde yüksek madde bağımlıı̆̆ı riskine işaret etmektedir. Çalışılan örneklemin (her iki cinsiyette de) \%19,5'i, madde bağımlılı̆ı riski göstermiştir (14). Bingöl'de 14 ve 18 yaşları arasındaki 1235 adölesanın dahil edildiği bir çalışmada, adölesanların \%15,8'inin sigara kullandığı, \%5'inin ise yaşam boyu en az bir kere sigara dışı bağımlılık yapıcı bir madde kullandığı saptanmıştır (25). İstanbul'da 2140 adölesan üzerinde yapılan geniş örneklemli bir çalışmada ise, adölesanların herhangi bir madde deneme oranı \%10,5; sürekli esrar kullanma oranı \%3,8; çoklu madde kullanım oranı ise \%9,7 olarak saptanmıştır (26). Farkı popülasyonlar üzerinde yapılan bu çalışmaların sonuçları, adölesanlarda madde kullanımının yaygınlığını gözler önüne sermektedir. Çalışmamızda, sigara kullandığını ifade eden adölesanların $(\% 40,8)$ nispeten yüksek oranda olması ise; mesleki eğitim merkezine devam eden adölesanlar üzerinde yapılmış olmasına bağlanabilir. Nitekim, Türkiye'de mesleki eğitim merkezine devam eden adölesanlar üzerinde yürütülen bir araştırmanının sonuçları da adölesanların \%50,5'inin sigara, \%36,0'ının alkol, \%6,2'sinin ise uyuşturucu/uyarıcı madde denediğini göstermiştir (27).

Çalışmaya katılan adölesanların sigara, alkol ya da diğer maddeleri kullanma durumlarının birbiri ile ilişkisi incelendiğinde; sigara kullanma durumu ile alkol ve diğer madde kullanımı arasında pozitif yönde, orta düzeyde, anlamlı bir ilişki olduğu belirlenmiştir. Çalışma bulgumuza benzer şekilde; Mete ve arkadaşlarının adölesanların sigara ve madde kullanma prevalansı ile sigara ve madde kullanımı arasındaki ilişkiyi belirlemek amacıyla gerçekleștirdikleri çalıșmada, sigara kullanan adölesanlarda sigara dışında bağımlılık yapıcı herhangi bir madde kullanma riskinin 8 kat yükseldiğinin tespit edilmesi dikkat çekici bir bulgudur (25). Mesleki eğitim merkezine devam eden adölesanlarla yapılan bir çalışmada da sigara kullananlarda alkol kullanımı sıklığının daha fazla olması araştırmamızın sonucuyla paralellik göstermektedir (27). Bu sonuca göre, sigaranın adölesanlar arasında alkol ya da diğer bağımlılık yapıcı maddelere geçme noktasında bir aracı ya da geçiş maddesi olarak kullanıldığını söylemek mümkündür. Bu durum da adölesanların sigara dışında bağımlılık yapıcı maddelerle temasını önlemede tütün bağımlıı̆ı ile mücadelenin önemini ortaya koymaktadır.

Çalışmamızda ailede alkol tüketen birinin varlığı ile adölesanların sigara, alkol ya da diğer maddeleri kullanma durumu arasında negatif yönde, zayıf, anlamlı bir ilişki olduğu bulunmuştur. Çalışmamızın aksine, Mısır'da 80 adölesanın dahil edildiği (40 madde kullanım bozukluğu olan ve 40 sağlıklı adölesan) bir vaka kontrol çalışmasında, madde kullanım bozukluğu olan adölesanların ailelerinde madde bağımlıı̆ı öyküsünün daha fazla olduğu saptanmıştır. Ailede madde bağımlılı̆ı öyküsü bu grupta 10 (\%25) iken bu oranın kontrol grubunda sadece 2 (\%5) olduğu ve aradaki farkın anlamlı olduğu görülmüştür (15). Bulgular arasındaki farkılığın, popülasyonlar arasındaki sosyal ve kültürel farklııklardan kaynaklandığı düşünülebilir.

Çalışmada kullanılan MBKÖÖ'nün kesme noktası bulunmadığından bulguların objektif verilerle kıyaslama olanağı bulunamamıştır. Çalışmaya katılan adölesanların MBKÖÖ toplam puan ve alt boyutlarından aldıkları puanlar incelendiğinde; alınan puanların ortalamanın üzerinde olduğu görülmüştür. Uzun ve Kelleci'nin lise öğrencilerinin madde bağımlılı̆ından korunma öz-yeterliklerini ve ilişkili faktörleri saptamayı amaçladıkları ve 911 adölesan ile yaptıkları çalışmanın bulguları, öğrencilerin MBKÖÖ'den orta düzeyin üzerinde $(100,49 \pm 18,97)$ puan aldıklarını göstermektedir (28). Çalışmamızda MBKÖÖ toplamından alınan ortalama puanın nispeten daha düşük $(76,47 \pm 28,31)$ bulunması, çalışmamızdaki örneklem grubunun bir mesleki eğitim merkezine devam eden adölesanlardan oluşması ve örneklem sayımızın düşük olmasıyla ilişkilendirilebilir. Alkol ve madde kullanımının okuldaki zorluklar, korunması cinsel ilişki, şiddet, intihar ve motorlu taşıt kazaları ile ilişkili olması nedeniyle, bu maddelerin kullanımı adölesanların şimdiki ve gelecekteki sağlığını çeşitli şekillerde tehlikeye atmaktadır (29). Bu bağlamda, adölesanlarda madde 
bağımlılıkarını önlemeyi amaçlayan politikalara, adölesanların madde bağımlıı̆ı̆ından korunma öz yeterliklerini optimum düzeye çıkarabilecek stratejilerin entegre edilmesinin yararlı olacağı düşünülmektedir.

Araştırmamızdaki adölesanların yaşları ile MBKÖÖ puanları arasında ilişki tespit edilmemiştir. Bulgumuzun aksine, lise ve üniversite öğrencileri ile yapılan çalışmalar madde bağımlıı̆̆ı konusunda yaşa göre risk artışı gözlemlemişlerdir. Illgili literatür incelendiğinde, 14-18 yaş grubundaki adölesanlarda yaşın 14'den 18'e yaklaşmasıyla birlikte sigara harici maddeleri kullanma riskinin takriben 1,5 kat yükseldiği (25); madde bağımılı̆̆ı riskinin 13 ila 14 yaş arası katılımcılarda \%7,9 iken, 18 ila 19 yaşları arasındaki grupta \%37,8'e yükseldiği (14); 17 yaş ve üzerindeki grubun madde bağımlığından korunma öz yeterlik düzeylerinin 16 yaş ve altındaki gruba göre daha düşük olduğu ve farkın anlamlı olduğu (28); üniversite 1. sınıf öğrencilerinin 4. sınıf öğrencileriyle kıyaslandığında uyuşturucu/uyarıcı maddelerden daha fazla uzak durdukları, uyuşturucu/uyarıcı maddeler konusunda daha fazla yardım aradıkları ve arkadaşlarına daha fazla destek oldukları (30) görülmektedir. Bu durum; adölesan dönemde yaşın ilerlemesiyle birlikte adölesanların bir gruba ait olma, kabul görme, karşı cins tarafından beğenilme gibi sosyal gereksinimlerinin arttığı ve sözü edilen gereksinimlerin karşılanması amacıyla adölesanların daha sık madde kullanma eğiliminde oldukları biçiminde yorumlanabilir. Bizim çalışmamızda yaş grupları ile MBKÖÖ'den alınan puanlar arasında ilişki bulunmaması ise, mesleki eğitim merkezine devam eden katılımclların profillerinin benzer özellik göstermesine bağlanabilir.

Çalışmamızda, cinsiyetlere göre MBKÖÖ toplam ve alt boyut puan ortalamaları incelendiğinde kadınların korunmaya yönelik öz yeterliklerinin daha yüksek olduğu bulunmuştur. Bulgumuzdan farklı olarak, Gaziantep'te 587 lise öğrencisiyle yapılan bir çalışmada kız ve erkek öğrencilerin madde bağımlıı̆ıından korunma öz yeterlik puanları arasında anlamlı bir farklılığa rastlanmamıştır (31). Kadınların madde bağımlılığından korunma öz yeterlik düzeylerindeki bu farkılığın; madde kullanımı konusunda kadın ve erkek arasındaki cinsiyet farkının daralması, kitle iletişim araçları ve sosyal medya etkisi, rol modellerin farklıık göstermesi gibi faktörlerden ve ayrıca örneklemimizdeki kadın sayısının az oluşundan etkilendiği düşünülebilir.

Çalışmamıza göre, annenin eğitim durumu adölesanların baskı altındayken uyuşturucu/uyarıı maddeden uzak durma durumunu etkilemektedir. Annesi ilköğretim mezunu olan adölesanların, annesi ortaöğretim ve üzeri mezunu olan adölesanlara göre baskı altında hayır diyebilme oranları daha düşüktür. Annenin çocuğun sağlıklı kişilik gelişiminde yadsınamayacak derecede önemli bir rol model işlevi gördüğü ve gelişim dönemindeki en önemli figürlerden biri olduğu dikkate alındığında (32), anne eğitim durumu arttıkça adölesanların hayır diyebilme becerilerinin yüksek olması da beklenen bir sonuçtur.

ABBÖ'nün aşııı koruma alt boyutundan alınabilecek puanların 0-21 arasında, ilgi-kontrol alt boyutundan alınabilecek puanların ise 0-54 arasında değişmekte olduğu (22) göz önünde bulundurulduğunda, araştırmamıza katılan adölesanların ilgi-kontrol alt boyutundan düşük, aşırı koruma alt boyutundan ise orta düzeyde puanlar aldıkları söylenebilir. Bu durum, çalışmaya katılan adölesanların ebeveyn tutumlarını az ilgili/kontrol edici ve orta düzeyde koruyucu olarak algıladıkları anlamına gelmektedir. Bir başka deyişle katılımcılar, ilgi-kontrol alt boyutunda soğuk ve reddedici; aşırı koruma alt boyutunda ise özerkliğe orta düzeyde izin veren bir ebeveyn tutumu algılamaktadır. Literatürde ailelerdeki ilişki nitelikleri üzerine yapılan ve adölesan madde bağımlıığının düşük aile uyumu ile 'şefkatsiz kontrol' olarak bilinen bir ebeveynlik tarzı tarafından etkilendiğini gösteren çalışmalardan bahsedilmektedir (33). Çalışmamızın örneklem grubundaki adölesanların madde kullanım yaygınlığı dikkate alındığında, bulgularımızın literatürle uyumlu olduğu görülmektedir. Bu noktada, olumsuz ebeveyn tutumlarının adölesanlarda madde kullanım riskini artırdığını söylememiz mümkündür.

Çalışmamızda MBKÖÖ puan ortalamaları ile ABBÖ puan ortalamaları arasındaki ilişki değerlendirildiğinde, her iki ölçek puan ortalamaları arasında istatistiksel olarak anlamlı bir ilişki olmadığı belirlendi. Literatürde ebeveyn bağlanma düzeylerinin, adölesanların madde bağımlı̆̆gndan korunma öz yeterliğini etkileme biçimine ilişkin yapılan bir çalışmaya rastlanmamıştır. Bunun yanında, adölesan dönemde bağlanma ve madde kullanım bozuklukları ile ilgili araştırmaları gözden geçiren bir çalışma; deneysel kanıtların, madde 
kullanım bozuklukları örneklerinde güvensiz bağlanma varsayımını güçlü bir şekilde desteklediğini vurgulamaktadır. Çalışmada, bağlanma ve madde kullanım bozuklukları arasındaki ilişkide bilinmeyenleri ele almak için halen çok fazla araştırmaya intiyaç duyulmasına rağmen, madde kullanım bozuklukları ve güvensiz bağlanma arasında genel bir bağlantı olduğuna dair güçlü kanıtlar bulunduğu ifade edilmektedir (34).

Araştırmamızdaki sigara ve alkol kullanan adölesanların anne ve baba ilgi-kontrol alt boyutlarının yüksek; alkol tüketen adölesanların anne ve baba aşırı koruma alt boyutlarının düşük; diğer maddeleri kullanmayan adölesanların kullanıp bırakanlara göre anne aşırı koruma puan ortalamasının daha yüksek olduğu saptandı. Bu durum; sigara kullanan adölesanların ebeveynlerinin daha ilgili; alkol kullanan adölesanların ebeveynlerinin daha ilgili ve özerkliğe izin veren; diğer maddeleri kullanan adölesanların ise annelerinin özerkliğe izin veren ebeveyn tutumlarına işaret etmektedir. Çalışmamızın aksine, yatarak tedavi gören alkol bağımlıları ile yapılan bir çalışmada, katılımcıların sadece \%33'ünde güvenli bir bağlanma şeklinin olması dikkat çekicidir. Çalışmada ayrıca güvensiz bağlanma tarzları erkeklerin \%65'inde ve kadınların \%69'unda bulunmuştur (35). Pakistan'da madde kullanım bozukluğu tanısı konmuş babalarla yaşayan 150 adölesanın dahil edildiği bir çalışmada ise, algılanan anne bağlanma ortalaması, algılanan baba bağlanmasına göre daha yüksektir (36). Bu bilgiler ışığında, adölesanlarda ya da ebeveynlerde var olan madde bağımlıı̆̆ı öyküsünün olumsuz bağlanma tarzlarına işaret ettiğini söylememiz mümkündür. Çalışmamızda ise sigara, alkol ya da diğer maddeleri kullanan adölesanların ebeveyn tutumlarını olumlu algılamaları; akran baskısı, merak, ilgi çekme, kabul görme, heyecan arayışı gibi aile ilişki niteliklerinden bağımsız faktörlerin madde kullanımını tetiklediğini düşündürmektedir.

Bu araştırmanın tek merkezli olması, adölesan bireylerle yüz yüze ve bire bir görüşme yapılamamış olması ve örneklem sayısının az olması çalışmanın kısıtlııklarıdır.

Sonuç olarak, çalışmaya katılan adölesanların madde kullanma riskini artıran faktörler; erkek cinsiyet, sigara kullanma durumu, anne eğitim düzeyinin düşük olması ve olumsuz ebeveyn tutumları olarak özetlenebilir. Bu bağlamda; özellikle tütün bağımlılığı ile mücadelede etkin çözüm önerileri üretilmesi ve ebeveyn tutumlarının madde kullanımı üzerindeki etkileri konusunda bilgilendirmelerin yapılacağı ebeveyn eğitim programları düzenlenmesi, riskin en aza indirilmesinde olumlu etkiler yaratabilir. Ayrıca, bağımlılıkları önleme politikalarına adölesanların madde bağımlıı̆ından korunma öz yeterliklerini artırma potansiyeli taşıyan stratejiler dâhil edilebilir. Buna ek olarak, adölesanların madde bağımılı̆̆ından korunma öz yeterlikleri ile ebeveyn bağlanma düzeyleri arasındaki ilişkinin geniş örneklem çalısmalarında değerlendirilmesinin daha iyi sonuçlar vereceği düşünülmektedir.

\section{Kaynaklar}

1. World Health Organization. Substabce abuse. 2017. Available from: https://www.who.int/topics/substance_abuse/en/. Accessed date: 03. 03. 2020.

2. Crews F, Boettiger C. Impulsivity, frontal lobes and risk for addiction. Pharmacol Biochem Behav 2009; 93: 237-247.

3. Pérez de Albéniz-Garrote G, Rubio-Rubio L, Medina-Gómez B. Moderating role of parental styles in the relationship between impulsivity and alcohol use in a sample of Spanish adolescents. Revista de Psicopatología y Psicología Clínica 2018; 23(1): 47-57.

4. United Nations. Sustainable Development Goals Indicators, Global Database. Available from: https://unstats.un.org/sdgs/indicators/database/ Accessed date: 04.03.2020.

5. Summers $P, O^{\prime}$ loughlin $\mathrm{R}, \mathrm{O}^{\prime}$ Donnell $\mathrm{S}$, et al. Repeated presentation of children and adolescents to the emergency department following self-harm: a retrospective audit of hospital data. Emerg Med Australas 2020; 32(2): 320-326.

6. Mielgo S, Lobrigados D, Calleja A, Cachero PA. Family risk factors in drug use. Psicología de las Adicciones 2012; 1: 7-11.

7. Oliva A, Parra Á, Sánchez I. Relationships with parents and peers as predictors of emotional and behavioural adjustment during adolescence. Apunt Psicol 2002; 20: 225-242. 
8. Ledoux S, Sizaret A, Hassler C, Choquet M. Consumption of psychoactive substances in adolescence. Analysis of cohort studies. Adicciones 2000; 12: 255-279.

9. Jiménez T, Musitu G, Murgui S. Family functioning and communication and adolescent drug use: Social support as a mediator. Rev Psicol Soc 2006; 21(1): 21-34.

10. Ceyhan E, Boysan M, Kadak MT. Associations between online addiction, attachment style, emotion regulation, depression and anxiety in general population: testing the proposed diagnostic criteria for internet addiction. Sleep and Hypnosis 2019; 21(2): 123-139.

11. Schreiber LRN, Grant JE, Odlaug BL. Emotion regulation and impulsivity in young adults. J Psychiatr Res 2012; 46(5): 651-658.

12. Bowlby J. Separation. Vol. 2. Attachment. New York: Basic Books, 1973: 126-133.

13. Parker JS, Benson MJ. Parent-adolescent relations and adolescent functioning: self-esteem, substance abuse, and delinquency. Adolescence 2004; 39(155): 519-530.

14. Cornellà-Font MG, Viñas-Poch $F$, Juárez-López JR, Malo-Cerrato S. Risk of addiction: Its prevalence in adolescence and its relationship with security of attachment and self-concept. Clínica Salud 2020; 31(1): 2125.

15. El-Fallah NA, Gad EA, Badawy AA, Abo Hamar SD. Psychological factors and family troubles among adolescents with drug use disorders. Med J Cairo Univ 2019; 87(6): 3933-3943.

16. Miljkovitch R. Addictive behaviours as a response to attachment insecurity. Corcos A. Pham-Scottez MS. (editors) Borderline personality disorder in adolescence. Paris, France: Dunod, 2013: 228-235.

17. Townsend MC. Psychiatric Mental Health Nursing: Concepts of Care in Evidence-Based Practice. 8th ed. Philadelphia: FA Davis Company, 2015: 365-418.

18. Ersü N, Ersü A, Acar B, et al. Lisede eğitim gören gençler ile çıraklık eğitim merkezine devam eden gençlerin sağlık risk ve problemlerinin karşılaştıııması. Sürekli Tıp Eğitimi Dergisi 2018; 27(5): 305-316.

19. Avcl D. The prevalence of substance use among adolescents participating in apprentices $\neg$ hip training, relationship between anger level-anger expression and addiction severity. J Psychiatr Nurs. 2017; 8(1): 1-8.

20. Lwanga SK, Lemeshow S, World Health Organization. Sample Size Determination in Health Studies: A Practical Manual. Geneva: World Health Organization; 1991.

21. Eker F, Akkuş D, Kapısız Ö. Ergenler için Madde Bağımılıı̆ı̆ndan Korunma Öz-Yeterlik Ölçeği'nin geliştirilmesi ve psikometrik değerlendirilmesi. Psikiyatri Hemşireliği Dergisi 2013; 4(1): 7-12.

22. Kapçı EG, Küçüker S. Ana babaya bağlanma ölçeği: Türk üniversite öğrencilerinde psikometrik özelliklerinin değerlendirilmesi. Turk Psikiyatri Derg. 2006; 17: 17-23.

23. World Health Organization. Child and Adolescent Mental Health Policies and Plans. Geneva: World Health Organization, 2005.

24. Sümer N, Oruçlular $Y$, Çapar T. Bağlanma ve bağımlılık: kuramsal çerçeve ve derleme çalışması. Bağımlılık Dergisi 2015; 16(4): 192-209.

25. Mete B, Söyiler V, Pehlivan E. Adölesanlarda sigara içme ve madde kullanma prevalansı. Bağımlılık Dergisi 2020; 21(1): 64-71.

26. Cömert IT, Ögel K. Madde kullanan ergenlerin bağlanma stilleri. Addicta: The Turkish Journal on Addictions 2014; 1(1): 9-40.

27. Yiğit Ü, Öncü E. Çalışan gençlerde sigara, alkol, uyuşturucu/uyarıcı madde kullanımı ve risk faktörleri. Addicta: The Turkish Journal on Addictions 2019; 6(4): 49-66.

28. Uzun S, Kelleci M. Lise öğrencilerinde madde bağımlılığ: Madde bağımlılığından korunma konusundaki öz yeterlikleri ve ilişkili faktörler. Dusunen Adam 2018; 31(4): 356-363.

29. Call KT, Riedel AA, Hein $K$, et al. Adolescent health and well-being in the twenty-first century: a global perspective. J Res Adolesc 2002; 12(1): 69-98.

30. Osmanoğlu DE. Üniversite öğrencilerinin içme nedenleri ve madde bağımlılı̆ından korunma öz-yeterlik davranışlarının belirlenmesi ve içme nedenlerine dair görüşleri. Atatürk Üniversitesi Kazım Karabekir Eğitim Fakültesi Dergisi 2017; 35: 198-222.

31. Yıldız M. Lise öğrencilerinin madde bağımlılığından korunmaya ilişkin öz-yeterliğinin incelenmesi. Uluslararası Eğitim, Bilim ve Teknoloji Dergisi 2017; 3(2): 70-77.

32. Özdemir 0, Özdemir PG, Kadak MT, Nasıroğlu S. Kişilik gelişimi. Psikiyatride Güncel Yaklaşımlar 2012; 4(4): 566-589.

33. Lewis AJ. Attachment-based family therapy for adolescent substance use: A move to the level of systems. Front Psychiatry. 2019; 10: 948.

34. Schindler A, Bröning S. A review on attachment and adolescent substance abuse: empirical evidence and implications for prevention and treatment. Subst Abus 2015; 36(3): 304-313. 


\section{Bağımlılık Dergisi - Journal of Dependence}

35. Wedekind D, Bandelow B, Heitmann S, et al. Attachment style, anxiety coping, and personality-styles in withdrawn alcohol addicted inpatients. Subst Abuse Treat Prev Policy. 2013; 8: 1.

36. Zia A, Shahzad S. Depression and perceived attachment of adolescents with fathers having substance-abuse disorder. J Pak Med Assoc 2019; 69(12): 1855-1859. 